\title{
The Semantics of Russian Genitive of Negation: The Nature and Role of Perspectival Structure
}

\author{
Barbara H. Partee \& Vladimir Borschev \\ UMass, Amherst \& VINITI, Russian Academy of Sciences and UMass, Amherst
}

\section{Introduction}

In many languages, existential sentences have a special syntactic shape, different from regular subject-predicate sentences. But in Russian, with its "freedom" of word order and lack of articles, the difference between existential and "plain" sentences is less obvious in many cases.
a. Vgorode byl doktor.
In town was-M.SG doctor-NOM.M.SG 'There was a doctor in town.'
b. Doktor byl v gorode.
doctor-NOM.M.SG was-M.SG in town
'The doctor was in town.'

The sentences in (1) seem to differ only in Theme-Rheme structure and word order (and correspondingly in definiteness of the bare NP); but under negation, the well-known "Genitive of Negation" (GenNeg) phenomenon distinguishes the two types sharply.

$$
\begin{array}{lllll}
\text { Otvet } & \text { ne prišel } & \text { - } & \text { Otveta } & \text { ne prišlo. } \\
\text { Answer-NOM.M.SG } & \text { NEG came-M.SG } & \text { - Answer-GEN.M.SG NEG came-N.SG } \\
\text { 'The answer didn't come.' } & \text { 'No answer came.' }
\end{array}
$$

Intransitive GenNeg sentences are always "impersonal": the verb is always N.SG . Babby (1980) introduced the terminology "Negated declarative sentences" (NDS), for the sentences with nominative subjects, (3a), and "Negated existential sentences" (NES), for those with genitive "subjects", (4a). The corresponding affirmative sentences (ADS and AES) are in (3b) and (4b).

NDS

(a) Otvet

$$
\text { iz polka ne prišel. }
$$

Answer-NOM.M.SG from regiment NEG anived-M.SG

'The answer from the regiment has not amived.'

ADS

(b) Otvet

iz polka prišel.

Answer-NOM.M.SG from regiment arrived-M.SG

'The answer from the regiment has anived.'

(4) NES (a) Otveta iz polka ne prišlo.

Answer-GEN.M.SG from regiment NEG anived-N.SG

'There was no answer from the regiment.'

AES

(b) Prišel otvet iz polka.

Arrived-M.SG answer-NOM.M.SG from regiment

'There was an answer from the regiment.' 
An affirmative AES obligatorily has a postverbal subject, while in a negative NES, where the difference is marked by case, the word order can vary. A common view among Russian linguists is that NES's are impersonal, but not AES's": "These sentences are impersonal only when negated. If one removes the negation, they become personal" (Peškovskij, 1938, p.334). Examples (5-8) illustrate alternating pairs and cases where either Gen or Nom is obligatory.
a. NDS: Stok
talyx vod
ne
- Runoff-NOM.M.SG melted water NEG
'No runoff of thawed snow was observed.'
b. NES:
a. NDS: Moroz ne črvstvovalsja.
Frost-NOM.M.SG NEG be.felt-M.SG
'The frost was not felt.' (E.g. we were dressed warmly).
b. NES: Moroza ne čuvstvovalos'.
Frost- GEN.M.SG NEG be.felt-N.SG
'No frost was felt (there was no frost).'
(7) a. NDS: *(\#) Somnenija ne byli.
Doubts-NOM.N.PL NEG were-N.PL
b. NES: Somnenij ne bylo.
Doubts- GEN.N.PL NEG were- N.SG
'There were no doubts.'
a. NDS: Lena ne pela.
Lena-NOM.F.SG NEG sang-F.SG
'Lena didn't sing.'
b. NES: *(\#) Leny ne pelo.
Lena-GEN.F.SG NEG sang-N.SG

nabljudalsja.

$\begin{array}{lllll}\text { Stoka } & \text { talyx } & \text { vod } & \text { ne } & \text { nabljudalos'. } \\ \text { Runoff-GEN.M.SG } & \text { melted water } & \text { NEG } & \text { was.observed-N.SG }\end{array}$

$\begin{array}{lllll}\text { Stoka } & \text { talyx } & \text { vod } & \text { ne } & \text { nabljudalos'. } \\ \text { Runoff-GEN.M.SG } & \text { melted water } & \text { NEG } & \text { was.observed-N.SG }\end{array}$

'No runoff of thawed snow was observed.' (= There was no runoff.)

In addition to this "subject Gen Neg", there is "object Gen Neg", in which Accusative alternates with Genitive under negation. The semantic effect in that case, if any, is less well understood, although some scholars such as Babyonyshev (1996) believe that is equally a matter of the scope of negation. Chvany (1975), Perlmutter (1978), Pesetsky (1982) and most Western scholars treat the two as a single phenomenon, but without proposing any common semantics other than that Gen Neg happens only under scope of negation. In some Slavic languages, the phenomena diverge. Russian linguists generally view the two constructions as distinct, with subject Gen Neg having clear semantic motivation and object Gen Neg lacking any systematic semantic effect. We return to this issue in Section 4.

\section{Babby on "Declarative" and "Existential" sentences}

\subsection{Information structure and the scope of negation.}

Babby's first main proposal about the distinction is shown in his chart (9) (Babby 1980: 72) below: DS's and ES's differ in their "scope of assertion/negation". 
(9)

\section{AFFIRMATIVE}

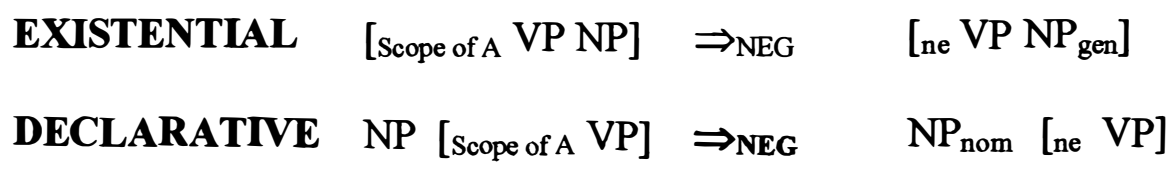

Thus the declarative sentence (5a) presupposes that there was some runoff of thawed snow and asserts that it was it was not observed, i.e. negates only that it was observed. The corresponding ES (5b) is used to negate the very existence of any runoff of thawed snow. The ES also negates "was observed", i.e. it negates the whole sentence; but in this case nabljudalsja 'was.observed' functions as a "weak verb" (often described as "semantically empty"). The notion of "weak" or "empty" verbs was at the center of the work reported in Borschev \& Partee (1998a); we will mention it in Section 3. Babby relates chart (9) to the categorical vs. thetic distinction (See Kuroda's (1972) discussion of Brentano and Marty; and see von Fintel (1989), Ladusaw (1994).)

Babby's second main proposal is that the scope of assertion/negation can be equated with the Rheme of the sentence according to the division of the sentence into Theme and Rheme (or Topic and Focus). Babby (2001) maintains the same correlation but adds a syntactic layer of analysis so that morphology does not have to interface with information structure directly. On Babby's view, an AES or NES is a "rheme-only" sentence (plus optional thematic locative.)

\section{Babby's (1980) rule of genitive marking in NES's:}

$$
\begin{array}{ll}
\text { [Rheme V NP] } & \text { NEG } \\
\text { Conditions: } & \text { (a) NP is indefinite } \\
& \text { (b) V is semantically empty }
\end{array}
$$

An approximate contemporary translation is "If the subject does not escape from the VP via topicalization, and the verb can be an 'existential verb', then negation licenses Genitive marking of the subject and Existential Closure (Diesing 1992b) applies." Our first principal amendment in Borschev \& Partee $(1998 \mathrm{a}, \mathrm{b})$ was to say that existence is always relative to a "LOCation", which may be implicit ${ }^{4}$. We accept Jackendoff's (1972, 1990) metaphorical-structural extensions of "being in a location" to include "being in some state", "occurring in some spatiotemporal region", "being in someone's possession", extending also to "being in the speaker's (or an observer's) perceptual field" (Padučeva 1992, 1997). Then whereas Babby analyzed ES's as "Rheme-only", with a possible optional Thematic Location, we argued that the LOCation, either given or contextually presupposed, is a semantically obligatory part of the construction and is the Theme. The assertion (Rheme) is that the/a "THING" described by the subject NP exists in that LOCation. 


\subsection{Alternatives to Babby's analysis: Unaccusativity.}

Babby $(1980,2001)$ claims that all subject Gen Neg sentences are existential. He argues that not all unaccusative verbs can occur with Gen Neg (see (11) from Babby 2001, p.43), and some unergative verbs can (see (12), Babby 2001, p.50).

(11) Za vse vremjasuda u nee nalice ne drognul ni odinmuskul. duringwhole time of-trial at her on face NEG twitched not one muscle.NOM 'Not a single muscle twitched on her face during the entire trial.'

$$
\begin{aligned}
& \text {..., tam ne rabotaet ni odnogo inženera. } \\
& \text {..., there NEG works not one.GEN engineer.GEN } \\
& \text { 'there hasn't been a single engineer working there' }
\end{aligned}
$$

Proponents of the Unaccusative analysis, from Perlmutter (1978) and Pesetsky (1982) to Harves (2002), would argue that being an underlying direct object is a necessary but not a sufficient condition for the occurrence of Gen Neg, so (11) needs further explanation but is not a "counterexample"; they would presumably argue that the verb has been shifted to an Unaccusative in (12). Both the restrictions needed for (11) and the shifts illustrated in (12) are clearly related to the semantics of the construction, which is our main concern.

Unaccusative sentences and Existential sentences share the property of "non-Agentivity". We remain agnostic about the Unaccusativity requirement, noting only that given the openness of the class of possible "genitive verbs", this approach will have to permit verbs to shift in and out of the Unaccusative class. We say more about 'verb shifts' in Section 3.

There are a great many analyses of Gen Neg in the literature, too many to discuss. Most Western Slavists consider Unaccusativity at least a necessary condition; few are explicit about the semantics of the construction other than that it occurs within the scope of sentential NEG. Babby and we are among the few to argue that subject Gen Neg sentences are existential.

\subsection{Approaches to the semantics of the construction.}

We will say more about the semantics of the construction in Sections 2 and 3. Here we mention a few key semantic pointers that come from previous work. A Gen Neg subject is typically indefinite, but not always (Babby, Timberlake.) The verb in a Subject Gen Neg sentence ${ }^{6}$ must be 'semantically empty' (Babby). Intransitive Gen Neg sentences are Thetic (Babby). (A number of authors appeal to Diesing $1992 \mathrm{~b}$ for the Nom/Gen alternation as VP-external vs. VP-internal subject.) Gen Neg occurs in the scope of sentential negation (according to just about everyone; but see Partee \& Borschev 2002). A Gen Neg NP (subject or object) has decreased referentiality and tends to be '(existentially) quantificational' (Jakobson, Timberlake, Babby, Neidle, Pesetsky, Bailyn). Especially for Object Gen Neg, many factors contribute to the (probabilistic) choice of Gen: decreased 'individuation' of NP, decreased transitivity of the verb (Timberlake, Mustajoki, Ueda). 


\section{Our approach: Existential vs. predicative and "Perspective structure"}

\subsection{It's not Theme-Rheme that distinguishes existential sentences}

As we have argued in several papers (Borschev \& Partee 1998b, 2002, in press; Partee \& Borschev 2002), we doubt the correlation of the NES - NDS distinction with the postulated difference in Theme-Rheme structure. Thus in Arutjunova's example (13) and our example (14), the words sobaki 'dog-GEN.F.SG', and kefira 'kefir-GEN.M.SG' are the Theme (or part of the Theme). Both their natural intonation pattern and their default interpretation in the given contexts support this point of view and argue against the generalization in (10).

Sobaki u menja net. (Arutjunova 1976)
dog-GEN.F.SG at I-GEN not.is
I don't have a dog. [Context: talking about dogs]
[Ja iskal kefir.] Kefira $\quad v$ magazine ne bylo.
[I looked-for kefir] Kefir-GEN.M.SG in store NEG was-N.SG
'[I was looking for kefir.] There wasn't any kefir in the store.'
(Borschev \& Partee 1998b, 2002)

So we agree with Babby that what is crucial is the distinction between declarative (predicative) and existential sentences, but not about the centrality of Theme-Rheme structure. We believe that what Babby observed was a nonaccidental correlation but not a crucial one; we come back to it at the end.

\subsection{What distinguishes "existential sentences"?}

\subsubsection{Making Location part of the story.}

Among the central notions needed for understanding existential sentences, Arutjunova (1976, 1997) distinguishes three components in a "classical" existential sentence: a "Localizer" ("Region of existence"), a name of an "Existing object", and an "Existential Verb". We have used different terms for the same notions: LOCation, THING, and BE.

Vètom kraju (Localizer) est' (Existential Verb) lesa ("Existing Object"). In that region is/are

'There are forests in that region.'

One could say that THING and LOC are roles of the verb byt' 'be', but it is undoubtedly better to consider them roles of the participants of the situation (or state) of existing or of being located. Thus, in the kefir sentence (14), THING is (what is denoted by) kefir ' $k e f i r$ ', and LOC is (what is denoted by) $v$ magazine 'in the store'.

The LOC may be given explicitly, as in (14), (15), or it may be implicitly understood, as in (2) or (6b). Existence is always understood with respect to some 
LOCation. An implicit LOCation must be given by the context. For (2), the LOC is the place where someone is awaiting a letter which "didn't arrive"; for (6b), it's the location of the perceiver who is "feeling (or not feeling) the frost". So one of the first principles behind our analysis is as follows.

"EXISTENCE IS RELATIVE" PRINCIPLE: Existence (in the sense relevant to AES's and NES's) is always relative to a LOC(ation).

Which location is an important question that we have addressed elsewhere and will not discuss here; see Borschev \& Partee 1998a, 2002.

\subsubsection{Existential sentences: LOC as Perspectival Center.}

There seems clearly to be a distinction, discussed by many authors in many frameworks, involving a contrast in two kinds of sentences each having the parts we call "BE (THING, LOC)", where BE stands for any "potentially existential" verb which can be used in both kinds of sentence. In an existential sentence, it is as if the predication is somehow "turned around", to assert of the LOCation that it has the THING in it. But in what way and at what "level" of structure is the predication "turned around"?

Babby (1980) proposed a difference at the level of Theme-Rheme (or Topic-Focus) structure. A number of linguists including Babby (2000) have proposed differences in syntactic structure, without taking a definite stand on the resulting semantics. We propose in Borschev \& Partee (2002) that in addition to topic-focus structure there is a relevant 'Perspectival Structure', relating to an often observed difference in predication in existential vs. predicational sentences. Both types have a verb with two arguments we call THING and LOCation.

In the unmarked structure, the THING is chosen as "Perspectival Center"; this is a predicational sentence. In an ES, the $\mathrm{LOC}^{7}$ is chosen as "Perspectival Center"; in some sense it turns the predication around: saying of the LOC that it has THING in it. If the LOC is implicit, this is a "thetic judgment".

\section{PERSPECTIVE STRUCTURE:}

An "existence/location situation" BE(THING, LOC) may be structured from the perspective of the THING or of the LOCation. We use the term Perspectival Center for the participant chosen as point of departure for structuring the situation.

An analogy may be made with a video camera and "what the camera is tracking". A predicational sentence keeps the camera fixed on the protagonist as she moves around (THING as Center); an ES is analogous to the way a security camera is fixed on a scene and records whatever is in that location (LOC as Center).

PERSPECTIVAL CENTER PRESUPPOSITION:

Any Perspectival Center must be normally be presupposed to exist. 
From principle (18) it will follow that the nominative subjects in NDS's are normally presupposed to exist, whereas in NES's, only the LOCation is normally presupposed to exist, and the perspectival structure does not provide any existence presupposition for the THING. This is confirmed by examples like (19).
a. Petja nakoncertene byl. Koncerta ne bylo.
Petja-NOM at concert NEG was-M.SG Concert NEG was-N.SG
'Petja was not at the concert. There was no concert.'
b. Peti na koncerte ne bylo \#Koncerta ne bylo.
Petja-GEN at concert NEG was-N.SG Concert NEG was-N.SG
'Petja was not at the concert. \#There was no concert.'

In the case of quantified NPs, the presupposition of existence becomes rather a presupposition that the domain of quantification is not empty. The nominative subject in (20) presupposes the existence of a non-empty set of students who 'might have been there', whereas the genitive subject in (21) carries no such presupposition.
[My nadejalis', čto na seminare budut studenty.]
No ni odin
[We hoped, that at seminar will.be students]
But NI one-NOM.M.SG
student
tam ne byl
student-NOM.M.SG there NEG was-M.SG.

['We hoped that (some of the) students would be at the seminar.] But not a single one of the students was there.'
[My nadejalis', čto na seminare budut studenty.]
[We hoped, that at seminar will.be students]
No ni odnogo
studenta tam ne bylo.
student-GEN.M.SG there NEG was-N.SG.
['We hoped that there would be students at the seminar.] But there was not a single student [or: not a single one of the students] there.'

\section{THE SEMANTICS OF NESs:}

An NES denies the existence of the thing(s) described by the subject NP in the Perspectival center LOCation. (not necessarily "in the world").

We have seen examples with implicit Perspectival Center locations associated with implicit observers. There are also cases, like (23), in which the implicit Perspectival Center location is simply "the actual world," yielding a literal denial of existence. In Borschev \& Partee (1998a), we related principle (22) to the principle in (24).
Edinorogov ne suščestvuet.
Unicorns-GEN.M.PL NEG exist-SG
'Unicorns do not exist.'

(24) PRESUPPOSED EQUIVALENCE: An NES presupposes that the following equivalence holds locally in the given context of utterance:

$$
\mathrm{V}(\mathrm{THING}, \underline{\mathrm{LOC}}) \Leftrightarrow \mathrm{BE}(\mathrm{THING}, \underline{\mathrm{LOC}})
$$


In the general case, we assume that verbs have their normal literal meaning, which in most cases is not simply "exist" or "be". If the GenNeg construction is used, the hearer uses contextual information to support an accommodation of the presupposition, perhaps shifting the verb meaning to make it "less agentive". Examples involving "axioms" deriving from lexical semantics, encyclopedic knowledge, and local contextual information are illustrated briefly in Section 3.

\subsection{Summary: Perspective and its role in Existential Sentences}

Perspectival structure is basically a structuring at the model-theoretic level, like the telic/atelic distinction, or the distinction between Agents and Experiencers. These properties reflect cognitive structuring of the domains that we use language to talk about, and are not simply "given" by the nature of the external world. Correspondingly, all of them are properties with respect to which we find differences from language to language.

There are two kinds of descriptions of situations containing a THING and a LOC. The situation may be described with the THING as Perspectival Center, or with the LOCation as Perspectival Center. The analogy is "what the camera is tracking." When the THING is chosen as Perspectival Center, its existence is presupposed, and the sentence speaks of its LOCation and potentially about other properties or states or actions in the situation. When we choose the LOCation as Perspectival Center, the sentence speaks about what THINGs there are or are not in that situation and potentially about what is happening in the situation.

The choice of Perspectival Center, as so described, has much in common with the choice of Theme (Topic) on the one hand, and with the choice of grammatical Subject on the other: all three notions involve structuring something (a situation, a proposition, or a sentence) so that one part is picked out and the rest is in effect predicated of it.

\section{What is perspective structure? Where in the grammar is it?}

\subsection{The camera metaphor.}

We noted above that Perspectival Structure is metaphorically similar to making a choice of what to track with a video camera: to follow some THING, or to stay fixed on a LOCation. So where in the grammar might such a notion belong?

It is not the same as information structure, although it has some similarity with it, and a chosen Perspectival Center may by default also be the Topic: but not always, as we showed with our kefir example (14). And it is not directly syntax, although it may well be reflected in the syntax. It seems primarily to be a choice of what structure we want to impose on some piece of reality that we want to describe. And in this it has something in common with deciding whether to describe a buying or a selling. It is similar in some ways to figure-ground choices, as in choosing whether to say that $\mathrm{A}$ is above $\mathrm{B}$ or that $\mathrm{B}$ is below $\mathrm{A}$. 


\subsection{Diathesis shifts.}

We want to develop this hypothesis and ground it more firmly in a broader theoretical context. Our current hypothesis about 'where in the grammar' the choice of Perspective Structure is registered is that it is a "diathesis choice", a choice among two alternative argument structures for verbs that can take both a "THING" and a "LOC" argument, analogous to the argument structure choices for verbs like spray, load or like give, send. (For give, send too there is a debate about whether the diathesis alternation corresponds to differences in semantics (Krifka 1999) or in information structure (Levin and Rappaport Hovav 2002)).

Other recent work on the semantics of diathetic alternations shares our goal of integrating lexical and compositional semantics by exploring which 'axioms' are contributed by lexical semantics and which by the semantics of the constructions (Ackerman and Moore 2001, Bresnan 1994, Dowty 2001, Kiparsky 1997, Krifka 1999). The relevant concept of diathesis originated in the Moscow School $^{8,}$ and research on the semantics associated with diathetic alternations has a long history in Russian semantics. We believe that research in this area can be greatly advanced if work in these two traditions can be brought together.

What is the semantic difference between load the truck with hay and load the hay on the truck? There is no systematic truth-conditional difference, but there are oft-noted differences in which argument is understood to be 'completely' affected, namely the one chosen as direct object, which is also the one more likely to be a definite NP. Is there a difference in the meaning of load when the argument structure shifts in this way? Yes (see more below.) We see these questions as similar to our questions about the status of the THING and LOC arguments in the two sentence types.

In current research on diathesis alternation, there are debates similar to our debate with Babby, about the relative contribution of topic-focus structure, lexical semantics, and the semantics of the syntactic structures. Both Levin and Rappaport Hovav (2002) and a number of Russian linguists (Yanko, Paducheva, and others) are convinced that lexical items may select for the informationstructure roles of certain of their arguments, in ways that may be connected to differences in presuppositional/assertional status of parts of their meanings. And while Krifka (1999) and Levin and Rappaport Hovav (2002) agree about many issues concerning diathesis alternation, they disagree about the English dative alternation. Both Krifka and Levin and Rappaport Hovav believe that there is a real semantic difference in the spray/load alternation, with the syntactic direct object as the semantically "affected object" in the two diathetic frames. (Fill the truck, or load all the hay.) But Levin and Rappaport Hovav believe that in the dative alternation, it's a matter of pragmatic implicature rather than semantic entailments. The issue is still open.

The differences between English and Russian "load"-type examples are considerable. English does more with syntax. Russian makes much more use of the derivational morphology of verbs - different prefixes, and imperfective vs. perfective forms - and the morphosyntax of the marking of the arguments. In English, it is common to find diathetic alternations in which only the syntax 
changes; in Russian it is rare to find such alternations without a change in the prefix on the verb or a change in aspect or both. Ackerman and Moore (2001) believe that both verb-centered and syntax-centered diathetic alternations are possible, and believe that Western theories may be helped by taking a more verbcentered perspective.

And indeed in the case of Gen Neg, not only do we often find semantic differences in the senses of the verbs when used with Gen vs. Nom (Section 3.3), or (less commonly but sometimes) with Gen vs. Acc, but we also find that Genitive "Subjects" do not score as highly on tests of subject properties as Nominative Subjects, tests which include both the kinds of semantic properties identified by Hopper and Thompson (1981) and Dowty (1991) and syntactic tests proposed by Keenan (1976). Keenan's and similar tests have been discussed with respect to Russian by Babby (1980) and by Testelets (2001).

But the fact that this alternation occurs only in negative sentences makes it different from many familiar diathetic shifts; we return to this issue presently.

\subsection{Evidence for lexical shifts: semantic "bleaching".}

In the framework of Borschev \& Partee (1998) we assume that the lexical verbs have their normal meanings, whatever those are. Then we ask: what types of further axioms can we find holding for the given $S$ in the given context, i.e. contained in the "theory" of the given $S$ in the given context, whose presence could contribute to making the equivalence in (24) a "locally valid" theorem? We argue that such axioms may come from the dictionary, from common knowledge, or from particular contextual information or inferences. A few examples are given below, but we omit discussion here.

- "Dictionary axioms".

a. NES: Ne belelo parusov na gorizonte.

NEG shone.white-N.SG sails-GEN.M.PL on horizon

'No sails were shining white on the horizon.'

b. Presupposed Equivalence:

'A sail shone white on the horizon.' $\Longleftrightarrow$ 'There was a sail on the horizon.'

c. 'Dictionary axiom' (part of lexical semantics): to shine-white $\Longrightarrow$ to be white (in the field of vision)

d. Dictionary or encyclopedic axiom; 'common knowledge': 'Sails as a rule are white.'

- Dictionary + contextual axioms

The force of the presupposed equivalence becomes even clearer if we pick an example in which the equivalence is less expected. 

NES: Ne belelo
domov
na gorizonte.
NEG shone.white-N.SG houses-GEN.M.PL on horizon
'No houses were shining white on the horizon.'

Example (26) is initially infelicitous in most contexts, but is acceptable if the hearer can accommodate the assumptions that all houses in the region are white, that the horizon is visible, and that there is an observer.

\section{- Axioms about characteristic actions or states for given kinds of things.}

The next example illustrates the general point that the occurrence of Gen Neg with accompanying 'semantic bleaching' often depends on the combination of verb and subject. Example (27a) is a NES, (27b) a NDS for contrast.

a. Vnašemlesu ne rastet gribov. (Babby 1980, p. 66)

In our forest NEG grows-SG mushrooms-GEN.M.PL

'There are no mushrooms growing in our forest.'

The general form for axioms of this kind is: for a thing of such-and-such a kind to exist (in a given location) is for it to perform a characteristic action or be in a characteristic state (in that location).

b. (Babby 1980 p. 67, ex. (72b), from Mir priključenij)

Zdes' daže trava ne rosla.

Here even grass-NOM.F.SG NEG grew-F.SG

'Even grass couldn't grow here'

\section{- “Genitive" verbs.}

Let us return now to the issue of which verbs can be "genitive" and the nature of their "weakness." What we conclude is that NES's may contain any verb which in a given context for one reason or another may be considered equivalent to be (or appear - "begin to be," etc.). If we take the equivalence in (24) as a presupposition of the construction, associated with this diathesis choice, we can view the resultant "semantic bleaching" of these verbs as a coerced lexical shift. Some of these shifts may be lexicalized; see the discussion of Mel'čuk's 'lexical functions' in Borschev \& Partee (1998a).

Since the axioms supporting this equivalence may come in part from the context in which the sentence is used, a full list of such verbs is impossible, as Babby noted. When the presupposed equivalence is inconsistent with presuppositions of the verb or of other parts of the sentence, or with our representation of reality, or with our suppositions about the given context, then the NES construction is impossible. The factors identified by Timberlake, Ueda, and other authors may be seen as factors making such a lexical shift easier or harder.

And conversely, some verbs virtually "demand" genitive, when the verb's meaning directly entails equivalence with be. With such verbs, like suščestvovat' 'to exist', the nominative is normally impossible: compare the impossible (28) with the normal example (23) cited earlier. The nominative is possible only in 
special cases involving non-standard "Locations", as illustrated in (29) (examples from Elena Paducheva, personal communication.)

$$
\begin{aligned}
& \text { \#Edinorogi ne suščestvujut. } \\
& \text { Unicorns-NOM.M.PL NEG exist-PL } \\
& \text { 'Unicorns do not exist.' }
\end{aligned}
$$
a. Ženščiny
dlja nego ne
suščestvujut.
Women-NOM.F.PL for him NEG exist-PL
'Women for him do not exist.'
b. Ženščin dlja nego ne suščestvuet.
Women-GEN.F.PL for him NEG exist-SG
'Women for him do not exist.'

The use of nominative in (29a) is marked, and signals the speaker's presupposition that in the actual world, women do exist. The use of the expected genitive in (29b) makes that sentence neutral; the speaker gives no particular signal as to whether he disagrees or agrees with "him".

\subsection{Why only under negation?}

One of the ongoing puzzles concerning Gen Neg is why the Nom/Gen and Acc/Gen alternations occur only in negative sentences ${ }^{9}$. This problem presents itself in different ways for different approaches, and accounts for the great wealth of literature on the syntax of the construction. For a diathesis-based account, it raises the question of how the verb and the negation are related.

Babby's 1980 account was explicit but stipulative, treating it as a construction, much as we have made it sound like in our account so far.

Pesetsky (1982) made progress toward an explanatory connection with negation when he posited that the Gen Neg NPs were all headed by a null NPI quantifier, which itself received the expected Nom or Acc case of its subject or object position, but assigned Gen to its complement, as many Russian quantificational heads do. Such an account also offered insight into the semantic property of 'decreased referentiality' often ascribed to Gen Neg NPs. But Pesetsky's account has problems with the fact that Gen Neg NPs are not always bare indefinites; they may have explicit quantifiers of their own (which then show up with Genitive case, not Nom or Acc), as in (21), and they may be headed by demonstratives, or be proper names, as in (19b).

It would be tempting to posit a 'negated verb' with its own diathesis shift. There are attested examples of languages with separate negated verbs, especially negations of 'be' or 'have', with their own argument structure, and in many Slavic languages, sentential negation is marked with a preverbal clitic or even a prefix. But as Bailyn (in press) describes, a number of accounts have foundered on the fact that the same negation that licenses Gen Neg only on the direct object of transitive verbs or the subject of some intransitive verbs also licenses NPIs 
(including negative concord $n$-words) in higher positions such as subject of a transitive or unergative verb.

Bailyn (in press) himself proposes that sentential Neg, in a relatively high position itself, licenses or checks a $\mathrm{Q}$ feature on the verb, and that $\mathrm{Q}$-marked verb may select for a genitive internal argument. That account has some features in common with Pesetsky's original idea, and also with the idea of (Jakobson 1971/1936), modernized in Neidle $(1982,1988)$, that genitive NPs are in some sense more quantificational than referential.

We believe that something along such lines could be semantically interpreted in a compositional way that could do justice to the interplay of compositional and lexical semantics and contextual factors. The basic idea would be that the verb shifts under negation to Neidle's/Bailyn's Q-marked verb, which is an NPI alternant of the original verb. Our "presupposed equivalence" is the semantics of this diathesis shift in the case of the intransitive; we are still wrestling with how to describe and account for the heterogeneity of effects with transitive verbs. Working this out will require further study of the issue of Object Gen Neg, to which we turn.

\section{What is the relation between Subject Gen Neg and Object Gen Neg?}

\subsection{Different but similar diathesis shifts.}

Are Subject and Object Gen Neg in Russian the same construction? Franks (1995), referring to arguments by Pesetsky $(1982)$ and Neidle $(1982,1988)$ that Gen Neg applies only to underlying internal arguments (direct objects), states "Their arguments that the genitive of negation pertains exclusively to objects are incontrovertible, I believe, ..." (p. 197). But we are not so certain, and our Russian colleagues remain skeptical.

Western Slavists (other than Babby) start from Object Gen Neg and see Subject Gen Neg as a derivative phenomenon involving only 'apparent' subjects. This approach does not offer any direct account of the "existential" interpretation of Subject Gen Neg sentences. Russian linguists are more inclined to see Subject Gen Neg as a property of existential sentences, and not to expect the same analysis to apply to Object Gen Neg sentences, which are not in any obvious sense "existential".

We believe that the two alternations are similar in that both involve a demotion of the corresponding argument: a genitive subject is not a first-class subject, and a genitive object is not a first-class object. But perhaps because objects are more closely dependent on the verb, the semantic effects of Object Gen Neg are variable, while the semantic effects of Subject Gen Neg fall into just one or two strong patterns, the existential type that we have mainly explored, and the ni odin type mentioned in two footnotes.

A problem for approach that takes Object Gen Neg as basic and extends it to Subject Gen Neg via the Unaccusativity hypothesis is that it does not explain why some but not all passive sentences allow Gen Neg subjects. With the verb 
polučit' 'receive', we find parallel behavior ${ }^{10}$ and interpretation between the object and a passive subject, illustrated in (30).

a. On ne polučil pis'ma.

he NEG received letter-GEN.N.SG

'He didn't receive any letter.'

b. Pis'ma ne bylo polučeno.

letter-GEN.N.SG NEG was-N.SG received

'No letter was received.'

c. On ne polučil pis'mo.

he NEG received letter-ACC.N.SG

'He didn't receive the letter.'

d. Pis'mo ne bylo polučeno.

letter-NOM.N.SG NEG was received

All are good, and the interpretations are parallel: Acc/Nom presupposes existence of the letter, Gen suggests no letter exists. But that is not true for all transitive verbs.
a. Ja ne čital ètoj
knigi.
I NEG read this-GEN.F.SG book-GEN.F.SG
'I didn't read this book.'
b. * ktoj knigi ne bylo pročitano.
this-GEN.F.SG book-GEN.F.SG NEG was-N.SG read-N.SG (Intended meaning: 'This book wasn't read.')

Our hypothesis about why the Gen is possible for the passive subject of polučen(o) but not for the passive subject of procitan(o) is that the passive predicate polučen $(o)$ is a bleachable 'existential' predicate similar to prišlo. It doesn't presuppose the existence of its subject, just as polučit' doesn't presuppose the existence of its object. Pročitan(o), on the other hand, cannot be construed as an existential predicate; it presupposes the existence of its subject.

We still need much more study of transitive verbs of different semantic classes. But even by itself this piece of data seems to constitute one argument against the Unaccusative Hypothesis. That hypothesis predicts that whenever the object of a transitive verb can occur in Gen Neg, the subject of the corresponding Passive should be able to occur in Gen Neg. But if the Subject Gen Neg rule and the Object Gen Neg rule have partly different conditions, with only Subject Gen Neg crucially demanding an "existential" reading, then one can account for the semantic licensing of passive Subject Gen Neg by the "existential reading" (bleachability) that some passive predicates have and others don't.

\subsection{A possible type-shifting approach to a 'demotion diathesis pattern'.}

Hypothesis: Wherever we see Nom/Gen and Acc/Gen alternation (both under negation and under intensional verbs), Nom or Acc represents an ordinary e-type 
argument position ('referential'; of course it may be quantified, etc.,), whereas a Gen NP is always interpreted as property-type: $\langle\mathrm{e}, \mathrm{t}\rangle$, or $\langle\mathrm{s},\langle\mathrm{e}, \mathrm{t}\rangle\rangle$.

A related hypothesis is that with the transitive analog of the existential sentence, and with verbs that have intensional objects ('ždat' 'expect, wait for', mentioned earlier), the 'genitive variant' of the verb has a (possibly implicit) situation argument which is higher ranked in some sense than the direct object, causing the direct object to be demoted, although it doesn't necessarily stop being object.

When the direct object is 'demoted', the structure does not provide a (situation-relative) existence presupposition, and the Genitive object may get a non-specific or a 'property' reading. In the Acc-taking structure, the (Acc) object is in canonical position, and the argument carries a (situation-relative) existence presupposition. In a Diesing-style (Diesing 1992b) approach (Babyonyshev 1996, Brown 1999), the Gen-object version might be the default, with the option of raising the object out of the VP (for Acc). On the lexical perspective this correlates with a change in verbal valency: When the verb is negated, it takes a 'weaker' kind of object, marked by Genitive.

In the case of the intensional verbs like $\check{z}$ dat' 'expect, wait for' in (34), one can argue that there is a shift in verb sense correlated with the shift in the interpretation of the object. So part of the hypothesis should be that the verb selects for the type of its object.
a. On ždet podrugu.
He waits girlfriend-ACC.F.SG
(Neidle 1988, p.31)
'He's waiting for his girlfriend.'
b. On ždet otveta na vopros.
He waits answer-GEN.M.SG to question
'He's waiting for an answer to the question.'

Neidle $(1988$, p. 31$)$ notes that verbs that lexically govern the genitive in Russian, optionally or obligatorily, "tend to be verbs of desire, aim, request, or achievement." When there is a choice, Accusative is used for a specific or generic object, indicating that the object is outside the scope of the semantic action of the verb. The Genitive is normally used when object is indefinite (existentially quantified) and within the scope of the verbal "operator".

As Neidle notes, there can be different ways of characterizing the difference: in terms of relative specificity of the NP object, or in terms of "the specification of the NP either within or outside of the scope of the action of the verb" (Neidle). She would like to say that in either case we are looking at differences in interpretation "associated with differences in the scope of the operation that I will refer to as 'specification'." (p.31)

The idea that such differences may reflect type differences relates closely to the work of Zimmermann (1993), who argued for an alternative to Montague's treatment of intensional verbs. Montague treated verbs like $\check{z} d a t$ ' as taking type $<\mathrm{s}<<\mathrm{e}, \mathrm{t}\rangle, \mathrm{t}\rangle>$ arguments, i.e. intensions of generalized quantifiers. Zimmermann argued that they rather take type $\langle\mathrm{s},<\mathrm{e}, \mathrm{t}\rangle\rangle$, properties of entities. BHP had 
resisted that idea for some time because of sentences like "The police were looking for every witness to the crime", which does allow an intensional reading for its clearly quantificational object, but overall Zimmermann's position is strong and we expect that BHP's counterarguments could be explained away with a little work.

Another clear connection is to the work of Helen de Hoop (1989, 1990, $1992,1995)$. She argued for a distinction between "weak case" and "strong case" for direct objects in Germanic languages, with both syntactic and semantic properties. Objects with "strong case" can move to topic position, can escape the scope of various operators, and are interpreted as e-type (or as generalized quantifiers if they are quantified). Objects with "weak case" cannot move far from the verb; they have to stay inside the VP, and consequently they fall under the scope of any operators that affect the VP. And they are interpreted quasiadverbially: they are of a type to take a transitive verb as argument and give an intransitive verb (phrase) meaning as result. This part of the proposal is slightly weak, because their adverb-like meaning appears to be just a type-lifted version of an existentially quantified argument-type meaning. But at least they are thereby restricted to having narrow scope indefinite meanings. This last point relates also to Diesing's work (Diesing 1992a,b, Diesing and Jelinek 1993).

There is a similar connection to the work of van Geenhoven (van Geenhoven 1995, 1996, 1998a,b), who treats 'weak' object NPs in West Greenlandic as "incorporated to the verb": they are not fully independent objects, but get an existential quantifier from the verb.

Yet another connection, and part of our immediate inspiration, is to the work of Ackerman and Moore (Ackerman and Moore 2001): variation in the semantic type of the object could be a species of diathesis, even if they are considered direct objects in both cases. Ackerman and Moore argue that "diathesis" should not be restricted only to cases where the actual grammatical relation changes, as in shifts from object to oblique, but also extended to cases where a subject or object remains subject or object but is 'weakened', and they cite alternations such as the well-known Accusative/Partitive alternations in Baltic languages among their case studies.

We need to look more closely at all the actual arguments invoked in these various analyses and see which of them have resonance with Russian Gen Neg and Russian objects of intensional verbs.

Now let us return to the issue of Subject Gen Neg and Object Gen Neg and connect the speculations above, which have mainly concerned Acc/Gen alternations, with Subject Gen Neg.

Given that we have analyzed Subject Gen Neg as always involving existential sentences, in the past we had trouble seeing how we could extend a comparable treatment to Object Gen Neg, since only in a small subset of cases does Object Gen Neg involve anything like "existential meanings": it seems to in (32a), but not in (33a), for instance. But if we study the arguments of McNally (1992, 1997, 1998) and recent work of Landman (2002), and ongoing work by Kamp and Bende Farkas, they all have argued that the NP in an existential sentence does not have normal type e (nor generalized quantifier) meaning, but 
rather a property type meaning $(<\mathrm{e}, \mathrm{t}>$ or $<\mathrm{s},<\mathrm{e}, \mathrm{t}>>)$ ). We have resisted that so far, because BHP has argued that that's the type for the predicate of copular sentences and NOT the type for the NP in existential sentences. But we could be wrong. Or this distinction in semantic types could be too rough to capture all the semantic distinctions that really need to be made.

If we could find more support for the arguments that the NP in an existential sentence is interpreted as property type $<\mathrm{e}, \mathrm{t}>^{11}$, whereas the subject position of a predicative or other ordinary sentence is type e, then the parallel between Subject Gen Neg and Object Gen Neg would be at a structural level: in each case the relevant argument is "demoted" from e-type to <e,t $>$-type, with syntactic and semantic consequences. The extent of the syntactic consequences apparently varies from language to language, and may vary within a language for Subjects vs. Objects; on many views, the Russian Gen Neg subject is no longer subject, but the Gen Neg object is still an object, although a 'weakened' one.

\section{Concluding remarks}

While we are still far from a full account, a picture may be emerging. In the Subject Gen Neg case, the Perspectival Center status of the LOCation and the corresponding demoted-subject status of the THING are both marked choices. A language which simply let one make the LOCation the subject would align subject and Perspectival Center, and syntactic predicate with what is predicated of it; that would represent a full 'syntacticization' of the distinction. On the other hand, there may well be languages which fit perfectly Babby's analysis of Russian, where the existential sentence was realized just by making the Perspectival Center the Theme and the rest of the sentence the Rheme. Russian seems to do something in between; the best way to characterize it syntactically is still not clear, but the LOCative has some subject-like properties, and the THING lacks many typical subject properties, perhaps because it is type-shifted to a property type.

The semantics of Object Gen Neg is less clear, and we have not given a full range of examples here. Nevertheless it seems plausible to think of Object Gen Neg as also involving a sort of diathesis shift, in which the negated verb may have a somewhat different semantics and diathesis frame than the corresponding non-negated verb: a decrease in transitivity properties, a decrease in referentiality of its direct object, and very often a removal of an existence presupposition. We have suggested that both Subject Gen Neg and Object Gen Neg may involve typeshifting the NP argument to a property type, which may be able to account for a number of the semantic correlates of the Gen Neg rule, and may help to link this investigation with other investigations of 'weak' objects (de Hoop 1995, Van Geenhoven 1998a, Zimmermann 1993).

This construction is interesting not only in its own right for the many puzzles it presents; it is also a good vehicle for exploring the interactions among lexical semantics of verbs, argument structures and their "rearrangements", the notion of existential constructions, and the pragmatics of assertion, negation, and presupposition. We are sure that we are still only scratching the surface. 


\section{Endnotes}

* We are grateful for valuable discussions and comments to more colleagues and students than we can list, including at least Peter Arkadiev, Tijana Ašić, Leonard Babby, John Bailyn, Chris Barker, Wayles Browne, Maria Nella Carminati, Catherine Chvany, Bernard Comrie, Östen Dahl, Nomi Erteschik-Shir, Hana Filip, Kai von Fintel, Jan Firbas, Robert Frank, Anastasia Giannakidou, Eva Hajičová, Uwe Junghanns, Hans Kamp, Chris Kennedy, Ji-yung Kim, Angelika Kratzer, Tony Kroch, Knud Lambrecht, Yury Lander, Fred Landman, Geraldine Legendre, Alexander Letuchiy, Elena Paducheva, Jaroslav Peregrin, Asya Pereltsvaig, David Perlmutter, David Pesetsky, Maria Polinsky, Ellen Prince, Ekaterina Rakhilina, Petr Sgall, Andreas Spaeth, Peggy Speas, Anita Steube, Anna Szabolcsi, Leonard Talmy, Yakov Testelets, and Tanya Yanko, and the participants in Partee's UMass seminar on Existential Sentences, Spring 2002 and subsequent audiences at MIT, OSU, in Nancy, Moscow, Prague, Tbilisi, UMass, Johns Hopkins, SALT 14 at Northwestern, and TAG+ 7 at Simon Fraser University. This work was supported in part by the National Science Foundation under Grant No. BCS-9905748 to both authors for the collaborative project "Integration of Lexical \& Compositional Semantics: Genitives in English and Russian", 1999-2003.

${ }^{1}$ Under a marked intonation, this sentence could also be a variant of 'The doctor was in town.' Our examples should be read with neutral intonation.

${ }^{2}$ In glossing our examples, we use the following abbreviations:

$\begin{array}{llll}\text { NOM } & \text { nominative } & \text { SG } & \text { singular } \\ \text { GEN } & \text { genitive } & \text { PL } & \text { plural } \\ \text { ACC } & \text { accusative } & 1 & \text { first person } \\ \text { M } & \text { masculine } & 2 & \text { second person } \\ \text { F } & \text { feminine } & 3 & \text { third person } \\ \text { N } & \text { neuter } & & \end{array}$

We use boldface to highlight the relevant occurrences of NOM and GEN on nouns and N.SG on non-agreeing verbs. We do not gloss irrelevant morphology.

${ }^{3}$ Perlmutter and Moore (2002) consider even the affirmative counterparts of these sentences, where the "subject" is necessarily nominative, to be impersonal constructions; so does Babby (2001).

${ }^{4}$ The claim that existential be-sentences always have an obligatory Locative argument is also made by Yokoyama (1986), Kondrashova (1996), and Comorovski (1995). Chvany (1975) emphasizes that no such argument is syntactically obligatory, while Kondrashova (1996) goes so far as to make the location the subject at her level of NP-structure.

${ }^{5} \mathrm{Gen} \mathrm{Neg}$ variants of (11) are supposed to be impossible (Babby 2001). But we have recently realized that Gen Neg variants of sentences like (11) are possible when they contain the emphatic negative focus particle $n i$; these are not existential sentences, and we are working on them separately for now.

${ }^{6}$ This applies to the existential sentences, not to the class of sentences noted in the previous footnote. 
${ }^{7}$ This is oversimplified; the term "LOCation" must be construed broadly, and the sentences are not only about existence but also 'coming into existence', 'being present', occurring, being in one's perceptual field, etc.

${ }^{8}$ Mel'čuk and Xolodovič (1970) and Xolodovič (1970) were the first to draw a distinction between voice and diathesis, using diathesis as the more general term for syntactic patterns of argument structure realization, reserving the term voice for diatheses marked on the verb (e.g. active/passive). The semantics of diathetic alternations continues to figure prominently in Russian lexical semantics (Padučeva 2002).

9 This is a point on which Slavic languages differ. Serbian/Croatian shows Nom/Gen alternation in both affirmative and negative sentences, although only with the verb be (Wayles Browne and Tijana Ašić, p.c.).

${ }^{10}$ Thanks to Alexander Letuchiy in BHP's semantics class at RGGU in Moscow in spring 2003 for bringing up this issue and helping to find these examples.

${ }^{11}$ We will say $<$ e,t $>$ for simplicity even though it may really be $<$, $<$ e, $t>>$.

\section{References}

Ackerman, Farrell, and Moore, John C. 2001. Proto-properties and Grammatical Encoding: A Correspondence Theory of Argument Selection: Stanford monographs in linguistics. Stanford, Calif: CSLI Publications.

Arutjunova, Nina D. 1976. Predloženie $i$ ego smysl [The Sentence and its Meaning]. Moscow: Nauka.

Arutjunova, Nina D. 1997. Bytijnye predloženija [Existential Sentences]. Enciklopedija "Russkij jazyk". Moscow: Bol’šaja Rossijskaja Enciklopedija, 57-59.

Babby, Leonard. 1980. Existential Sentences and Negation in Russian. Ann Arbor, Michigan: Karoma Publishers.

Babby, Leonard. ms. 2000. The genitive of negation and unaccusativity. Ms., Princeton University.

Babby, Leonard H. 2001. The genitive of negation: a unified analysis. In Annual Workshop on Formal Approaches to Slavic Linguistics: The Bloomington Meeting 2000 (FASL 9), eds. Steven Franks, Tracy Holloway King and Michael Yadroff, 39-55. Ann Arbor: Michigan Slavic Publications.

Babyonyshev, Maria A. 1996. Structural Connections in Syntax and Processing: Studies in Russian and Japanese. Ph.D. dissertation, MT. MT Working Papers in Linguistics, Cambridge, MA.

Bailyn, John F. 1997. Genitive of negation is obligatory. In Annual Workshop on Formal Approaches to Slavic Linguistics: The Cornell Meeting 1995. [= FASL 4], eds. Wayles Browne, Ewa Dornsich, Natasha Kondrashova, and Draga Zec., 84-114. Ann Arbor, Michigan: Michigan Slavic Publications.

Bailyn, John Frederick. In Press. The Case of Q. In Proceedings of FASL 12, ed. O. Arnaudova et. al. Ann Arbor: Michigan Slavic Publications. 
Borschev, Vladimir and Barbara H. Partee. 1998a. Formal and Lexical Semantics and the Genitive in Negated Existential Sentences in Russian. In Formal Approaches to Slavic Linguistics: The Connecticut Meeting 1997, eds. Željko Bosković, Steven Franks and William Snyder, 75-96. Ann Arbor: Michigan Slavic Publications.

Borschev, Vladimir and Barbara H. Partee. 1998b. Bytijnye predloženija i otricanie $\mathrm{v}$ russkom jazyke: semantika i kommunikativnaja struktura. [Existential sentences and negation in Russian: semantics and communicative structure]. In Dialogue '98: Computational Linguistics and its Applications, ed. A.S. Narin'yani, 173-182. Kazan: Xéter.

Borschev, Vladimir, and Barbara H. Partee. 2002. The Russian genitive of negation in existential sentences: the role of Theme-Rheme structure reconsidered. In Travaux du Cercle Linguistique de Prague (nouvelle série), eds. Eva Hajicová, Petr Sgall, Jirí Hana and Tomáš Hoskovec, 185250. Amsterdam: John Benjamins Pub. Co.

Borschev, Vladimir, and Partee, Barbara H. in press. The Russian genitive of negation: Theme-rheme structure or perspective structure? Journal of Slavic Linguistics 10 ("2002"):101-140.

Bresnan, Joan. 1994. Locative inversion and the architecture of Universal Grammar. Language 70:72-131.

Bresnan, J. K., Jonni M. (1989). "Locative Inversion in Chicheŵa: A Case Study of Factorization in Grammar." Linguistic Inquiry 20: 1-50.

Brown, Sue. 1999. The Syntax of Negation in Russian: A Minimalist Approach. Stanford: CSLI Pubs.

Chvany, Catherine V. 1975. On the Syntax of BE-Sentences in Russian. Cambridge, MA: Slavica.

Comorovski, Ileana. 1995. On quantifier strength and partitive noun phrases. In Quantification in Natural Languages, eds. E. Bach, E. Jelinek, A. Kratzer and B. H. Partee, 145-177. Dordrecht: Kluwer.

Diesing, Molly. 1992a. Bare Plural Subjects and the Derivation of Logical Representations. Linguistic Inquiry 22:353-380.

Diesing, Molly. 1992b. Indefinites. Cambridge, MA: MIT Press.

Diesing, Molly, and Jelinek, Eloise. 1993. The Syntax and Semantics of Object Shift. Working Papers in Scandinavian Syntax 51.

Dowty, David. 1991. Thematic proto-roles and argument selection. Language 67:547-619.

Dowty, David. 2001. The semantic asymmetry of 'argument alternations' (and why it matters). In Groninger Arbeiten zur germanistischen Linguistik Nr. 44, eds. Geart van der Meer and Alice G. B. ter Meulen. Groningen: Center for Language and Cognition.

von Fintel, Kai. 1989. Theticity in Generative Grammar. In Papers on Quantification, eds. Emmon Bach, Angelika Kratzer and Barbara Partee: University of Massachusetts at Amherst.

Franks, Steven. 1995. Parameters of Slavic Morphosyntax. Oxford: Oxford University Press. 
Van Geenhoven, Veerle. 1995. Semantic incorporation: a uniform semantics for West Greenlandic noun incorporation and West Germanic bare plural configurations. In CLS 31: Papers from the Thirty First Meeting of the Chicago Linguistic Society. Chicago: Chicago Linguistic Society.

Van Geenhoven, Veerle. 1996. Semantic Incorporation and Indefinite Descriptions: Semantic and Syntactic Aspects of Noun Incorporation in West Greenlandic, University of Tübingen: Ph.D. Dissertation.

Van Geenhoven, Veerle. 1998a. Semantic Incorporation and Indefinite Descriptions: Semantic and Syntactic Aspects of Noun Incorporation in West Greenlandic: Dissertations in linguistics. Stanford, Calif.: CSLI Publications.

Van Geenhoven, Veerle. 1998b. On the argument structure of some noun incorporating verbs in West Greenlandic. In The projection of arguments: Lexical and compositinal factors, eds. Miriam Butt and Wilhelm Geuder, 225-263. Stanford: CSLI Publications.

Hajičová, Eva, Barbara H. Partee, and Petr Sgall. 1998. Topic-focus articulation, tripartite structures, and semantic content. Dordrecht: Kluwer.

Harves, Stephanie (2002) Unaccusative Syntax in Russian. Ph.D. dissertation, Princeton.

de Hoop, Helen. 1989. Case assignment and generalized quantifiers. In Proceedings of NELS 19, 176-190. Amherst, MA: GLSA.

de Hoop, Helen. 1990. Restrictions on existential sentences and objectscrambling: Some facts from Dutch. In The Proceedings of WCCFL 9, ed. Aaron L. Halpern, 277-288. Stanford, Calif.

de Hoop, Helen. 1992. Case configuration and noun phrase interpretation, University of Groningen: Ph. D. Dissertation.

de Hoop, Helen. 1995. On the characterization of the weak-strong distinction. In Quantification in Natural Languages, eds. Emmon Bach, Eloise Jelinek, Angelika Kratzer and Barbara H. Partee, 421-450. Dordrecht: Kluwer.

Hopper, Paul, and Thompson, Sandra. 1981. Transitivity in grammar and discourse. Language 56:251-299.

Jackendoff, Ray. 1972. Semantic Interpretation in Generative Grammar. Cambridge: MIT Press.

Jackendoff, Ray. 1990. Semantic Structures. Cambridge: MIT Press.

Jakobson, Roman. 1971/1936. Beitrag zur allgemeinen Kasuslehre: Gesamtbedeutungen der russische Kasus. In Selected Writings II, 23-71. The Hague: Mouton (originally published in 1936).

Keenan, Edward. 1976. Towards a Universal Definition of "Subject". In Subject and Topic, ed. Charles Li, 303-333. New York: Academic Press.

Kiparsky, Paul. 1997. Remarks on denominal verbs. In Complex Predicates, eds. Alex Alsina, Joan Bresnan and Peter Sells, 473-500. Stanford: CSLI Publications.

Kondrashova, Natalia. 1996. The Syntax of Existential Quantification. Ph.D. dissertation, University of Wisconsin, Madison. 
Krifka, Manfred. 1999. Manner in dative alternation. In WCCFL 18: Proceedings of the Eighteenth West Coast Conference on Formal Linguistics, eds. Sonya Bird, Andrew Carnie, Jason D. Haugen and Peter Norquest, 1-14. Somerville/Medford, MA: Cascadilla Press.

Kuroda, S.-Y. 1972. The categorical and the thetic judgment (evidence from Japanese). Foundations of Language 2, 153-185.

Ladusaw, William A. 1994. Thetic and categorical, stage and individual, weak and strong. In SALT IV: Proceedings of the Second Conference on Semantics and Linguistic Theory 1994, eds. Mandy Harvey and Lynn Santelmann, 220-229. Ithaca, N.Y.: CLC Publications, Department of Linguistics, Cornell University.

Levin, Beth, and Rappaport Hovav, Malka. 2002. Handout Spain: What Alternates in the Dative Alternation?: The 2002 Conference on Role and Reference Grammar: New Topics in Functional Linguistics: The Cognitive and Discoursive Dimension of Morphology, Syntax and Semantics, Universidad de La Rioja, Logrono, Spain, July 27-28, 2002.

Mel'čuk, I.A., and Xolodovič, A.A. 1970. K teorii grammatičeskogo zaloga 'Towards a theory of grammatical voice'. Narody Azii i Afriki 4:111-124.

Mustajoki, A. 1985. Padež dopolnenija v russkix otricatel'nyx predloženijax 1: Izyskanija novyx metodov v izučenii staroj problemy. [Case of the object in Russian negative sentences 1: Development of new methods and study of an old problem.] Slavica Helsingiensia 2. Helsinki: Helsinki University Press.

Mustajoki, Arto, and Heino, Hannes. 1991. Case selection for the direct object in Russian negative clauses. Part II! Report on a Statistical Analysis: Slavica Helsingiensia 9. Helsinki: Department of Slavonic Languages, University of Helsinki.

Neidle, Carol. 1982. The Role of Case in Russian Syntax, Ph.D. dissertation. Cambridge: MIT.

Neidle, Carol. 1988. The Role of Case in Russian Syntax: Studies in Natural Language and Linguistic Theory 10. Dordrecht: Kluwer.

Padučeva, Elena V. 1992. O semantičiskeskom podxode k sintaksisu i genitivnom sub"ekte glagola BYT' [On the semantic approach to syntax and the genitive subject of the verb BYT' 'BE']. Russian Linguistics 16:53-63.

Padučeva, Elena V. 1997. Roditel'nyj sub"ekta v otricatel'nom predloženii: sintaksis ili semantika? [Genitive of Subject in a negated sentence: syntax or semantics?]. Voprosy Jazykoznanija 2: 101-116.

Padučeva, E.V. 2002. Diateza i diateticheskij sdvig ('Diathesis and diathesis shift'). Russian Linguistics 26:179-215.

Partee, Barbara H. 2000. Topics under negation: But the answer never came. In Johannes Dölling and Thomas Pechmann, eds., Prosodie - Struktur Interpretation. Linguistiche ArbeitsBerichte 74, 43-57. Leipzig: University of Leipzig. 
Partee, Barbara H., and Vladimir Borschev. 2002. Genitive of negation and scope of negation in Russian existential sentences. In Annual Workshop on Formal Approaches to Slavic Linguistics: the Second Ann Arbor Meeting 2001 ( $F A S L$ 10), ed. Jindrich Toman, 181-200. Ann Arbor: Michigan Slavic Publications.

Perlmutter, D. 1978. Impersonal passive and the Unaccusative Hypothesis. In Proceedings of the fourth annual meeting of the Berkeley Linguistics Society. J. Jaeger et al.(eds.) University of California at Berkeley. 159189.

Perlmutter, David, and Moore, John. 2002. Language-internal explanation: The distribution of Russian impersonals. Language 78:619-650.

Pesetsky, David. 1982. Paths and Categories. Ph.D. dissertation. Cambridge: MIT.

Peškovskij, Alexandr M. 1938. Russkij sintaksis v naučnom osveščenii [Russian syntax in a scientific light]. 6nd edition. Moscow: Gosučpedgiz.

Testelets, Yakov G. 2001. Vvedenie v obščij sintaksis [Introduction to General Syntax]. Moscow: Rossijskij Gosudarstvennyj Gumanitarnyj Universitet (RGGU).

Timberlake, Alan. 1975. Hierarchies in the Genitive of Negation. Slavic and East European Journal 19:123-138. Reprinted in Case in Slavic, ed. R.D.Brecht and J.S.Levine. Columbus: Slavica, 1986, 338-360.

Ueda, Masako. 1993. Set-membership interpretations and the genitive of negation. Russian Linguistics 17:237-261.

Xolodovič, A. A. 1970. Zalog. I: Opredelenie. Isčislenie. [Voice. I: Definition. Calculus.]. In Kategorija zaloga. Materialy konferencii. [The Category of Voice. Conference Materials.], 2-26. Leningrad.

Yokoyama, Olga T. 1986. Discourse and Word order. Amsterdam: John Benjamins.

Zimmermann, Thomas Ede. 1993. On the proper treatment of opacity in certain verbs. Natural Language Semantics 1:149-179. 